\title{
On the Problem of the Studentship's Cultural Identity Development
}

\author{
Semyon D. Voroshin* \\ South Ural State University \\ National Research University \\ 76 Lenin, Chelyabinsk, 454080, Russia
}

Received 23.06.2017, received in revised form 17.08.2017, accepted 25.08.2017

This article deals with the study of the problem of the university museum's participation in the studentship's cultural identity development. The author studies the activity of the Hall of Arts of the Art Museum of the South Ural State University (SUSU). The influence of the art exhibition process on the development of different levels of the students' identity has been demonstrated. Academic exhibitions of the Hall of Arts of different content have been analyzed. The influence of exhibitions by artists of the South Ural on the development of different levels of studentship's identity has been studied. The role of global, national and regional exhibitions in the university's cultural life has been demonstrated.

Keywords: university museums, museum activities of the university, studentship's cultural identity, Hall of Arts of the South Ural State University.

DOI: 10.17516/1997-1370-0147.

Research area: culturology.

With today's increasing globalization trends, the issue of self-determination of a person in society is one of the up-to-date questions. Recent researches tend to study the process of self-determination in the context of the "cultural identity" concept.

In modern science, identity is understood as one's self-perception as an integral personality interrelated with various social groups, implying a certain way of thinking and actions. This process is a product of the identification mechanism that ensures co-operation between subjects in a social group and existence of a person in the society (Khamnaeva, 2007). It is based on the aggregate of all social bonds available to an individual. The $20^{\text {th }}$ century's US scientist Eric Ericsson, the founder of the identity doctrine, believed that the roots of this process go down into the earlier age, when a person has to perform various social roles and match them against the available information on his/her personality in order to plan his/her future (Ericsson,1996).

General identity matters are elaborated in the works by A.G. Rusanova, I.V. Mishina, E.A. Grishina, A.A. Nikonova, T.A. Fomina, D.N. Shul'gina, V.A. Iadov, M.B. Melekhina, G.P. Kaldinova, V.M. Gusman, D.S. Dokuchev, M.V. Nazukina (Nazukina, 2009). The question

(C) Siberian Federal University. All rights reserved

* Corresponding author E-mail address: svoroshin@mail.ru 
of students' identity development is the focus of attention of E.A. Klimov, M.V. Shuklinova, N.A. Samoylik, Iu.P. Povarenkova, G.V. Garbuzova, E.P. Ermolaeva， A.A. Ozerina， L.V. Rozhkova, E.M. Arutiunova (Rozhkova, 2010). Cultural identity development by means of arts is addressed in the works by N.P. Koptseva, M.A. Kolesnik, A.V. Kistova, A.V. Mazurik, K.V. Reznikova, A.A. Semenova, N.N. Seredkina (Kolesnik, 2014; Koptseva, 2012; Koptseva, 2013; Koptseva, Kistova, 2015).

Complexity of the cultural knowledge accumulation processes in the context of its emotional impact is conditioned by a multi-level structure of personal self-identity. Scientists describe several types of cultural identity, the most global of which is self-determination of an individual, which implies identity with universal norms and values (Shul'gina, 2010). Considering the modern trends of globalization and crosscultural interaction, this level is important in understanding current problems of the humankind; however, it can just as well deprive a person of his/ her attachment to the identity of his/her native culture (Smakotina, 2010). This gap in personality development is filled with the nation-wide identity. It implies individual's affiliation with the society and culture of his/her country. Thus, a natural human need for affiliation with society is fulfilled through adoption of country's basic symbols, concepts and values (Kolesnik, 2014; Koptseva, 2012; Koptseva, 2013; Koptseva, Kistova, 2015).

In the context of modern tendency to globalization, preservation of unique cultures gains great importance; there is an increasing role of one's affiliation not only with the country as a whole, but also with the culture and life of the region and, as a result, finding oneself as a full-fledged citizen. Regional identity means understanding the unique character of the region and using this process as the basis for society integration. It describes peculiarities of a local community in the human world outlook and ensures its existence, resulting, in its turn, from selective traditions that establish emotional commitment to this culture. History of the region embodied in symbols and veneration of local heroes acts as raw material. It also serves as a semantic context for differentiation between communities (Nazukina, 2009).

Alongside with the levels conditioned by the place of residence, another significant type of personal self-identification is spiritual identity. It describes individual's understanding of his/ her affiliation with this or that religion in the cultural, if not in the confessional way (Pronina, 2016). Moreover, today fulfilment of one's professional potential is also a significant process in self-determination in addition to his/her affiliation with the global community, country and region. Socially, it is manifested in personal identification with a particular professional group and adoption of the values and norms of a certain expert community (Ozerina, 2012).

So, identity is a multidimensional phenomenon. It is built on multiple levels and establishes both universal values and individual's perception of the peculiarities of the culture of his/her country and region. The phenomenon of student cultural identity becomes an important concept. Higher educational institutions of the Russian Federation have elaborated a system for its establishment, where an important role is played by university museums (Rozhkova, 2010; Shuklinova, 2005). Arrangement of the museums matches scientific-methodological and information-communication concepts of the university education system intended to improve the process of learning, social and public status of the university and establish cultural framework of the region (Voroshin, 2017a; Voroshin, 2017b; Parfent'eva, Parfent'ev, 2010).

Let us elaborate on students' cultural identity development process on the basis of 
the museums of the South Ural State University (National Research University).

Being the largest university of the region, SUSU has a well-developed museum infrastructure that comprises: University History Museum, Training Centre for Rocket-andSpace Technology named after Academician V.P. Makeev, Archaeological Museum "Peoples and Technologies of the Urals", Art Museum, Training Geological Museum, Museum of Money, Yu.L. Teush's Photo Gallery. The SUSU's Art Museum was founded in 2003. The works of art found at the university combined with the majestic impression of the university's architecture produce strong educational and aesthetic influence on students (Parfent'ev, 2010a; Parfent'eva, 2010a; Parfent'eva, 2010b). The complex of the SUSU's Art Museum comprises the Hall of Arts, Art Laboratory, Multimedia Information and Education Centre "Virtual Branch of the State Russian Museum" ("Pushkin's Hall”), art collection storage (Parfent'eva, 2013; Parfent'eva, 2010c; Parfent'eva, 2009; Parfent'eva, 2010d; Parfent'eva, 2009; Trifonova, 2009a; Trifonova, 2009b; Trifonova, 2011; Rusanov, 2010).

The museum facility operates in three main directions: exhibitions, museum collections, information and resources. In particular, the primary function of the exhibition Hall of Arts is training and education (Parfent'ev, 2010a). In addition to exhibition management, the employees of the Hall of Arts are engaged in organizing events intended to create a trusting dialog between visitors and works of art: giving tours to Theology, Culture and Arts department students and employees, arranging conferences dedicated to various architects and artists, with meeting painters of the country and region, outstanding men of art and science. All these stimulate the development of students' cultural identity through the works of art in the context of the "live" museum concept development.
Since the year 2003, the Hall of Arts has hosted 122 exhibitions. The exhibitions of the Hall of Arts may be divided into several categories. The first is exhibitions of classical art works from state museum funds. These exhibitions are academic in fact, and have a significant historical and cultural value. Normally, such works have a time span and belong to the country's major museums or private collections. At various times, the Hall of Arts has exhibited the works from the State Russian Museum, Yekaterinburg Museum of Fine Arts, Chelyabinsk State Museum of Fine Arts, Nizhny Tagil Municipal Museum of Fine Arts, N.K. Rerikh Museum in Novosibirsk, Russian Academy of Arts.

Academic exhibitions of the Hall of Arts may be classified on the basis of the cultural identity level they instil in students. Based on this principle, the exhibitions are divided into four phenomenon development levels: global, national, regional and spiritual.

The global level of students' cultural identity development the object of such exhibitions as "Western European engraving of the $16^{\text {th }}-19^{\text {th }}$ centuries. Portraits of natural scientists" (09.10.03-08.11.03) from the collection of Chelyabinsk engineer, scientist, collector and bibliophile, descendant of the outstanding academician L. Eiler (1707-1783), Genrikh Fernandovich Otten. The exhibition "Raffaello's Madonna from Nizhny Tagil” (14.02.12-15.03.12) displayed three pieces: "Madonna del Popolo" allegedly painted by Raffaello Santi (1509), "Madonna and Child with St. John the Baptist" by G.C. Procaccini (1570-1625) and a replica of "Madonna del Granduca" by Raffaello (1506) made in 1874 by French artist E. Rouillon.

Another highlight of the Hall of Arts was the exhibition titled "Mountain lake in the Urals" (16.11.05-25.03.06). It was organized in cooperation with Chelyabinsk State Museum of Fine Arts and State Russian Museum, and comprised 
works of all-Russian standing. Apart from "Mountain lake in the Urals" by A.M. Vasnetsov, the exhibition displayed five more works by the renowned Russian artists of the $19^{\text {th }}$ century: K.V. Lebedev (1852-1916), M.K. Klodt (18321902), V.D. Polenov (1844-1927), V.M. Vasnetsov (1848-1926) and S.Yu. Zhukovsky (1873-1944) (Kolesnik, 2014).

The following exhibitions of icons featured an outstanding academic level: "Traditions of the Old Russian Art in the Ural Culture" (23.04.0426.05.04) and "The Ural Icon" (24.05.0630.06.06). These exhibitions displayed icons, early printed books, cast copper plastic art of the $16^{\text {th }}-20^{\text {th }}$ centuries (Schennikova, 2004). The icon is shown not only as a sacred object, but also as a symbol of Russia tracing its roots in Byzantium. This introduction into the world of Old Russian art has contributed to the formation of spirituality as one of fundamental aspects of students' culture. Academic exhibitions offered a unique opportunity to get in touch with eternal art and displayed classical works by international and Russian artists. Recognition of the fact that some priceless collections have been gathered by residents of the Urals and Chelyabinsk city, offers a new insight into the culture of the region.

Exhibitions of regional artists present artistic images of nature, people, urban and rural ways of life of the South Urals. Among 121 exhibitions held at the SUSU Art Museum, 34 were dedicated to professional South Ural artists. Photographic exhibitions of the Hall of Arts were the highlights. We would like to mention the most significant international photographic exhibitions, such as "Marina Tsvetaeva in Prague" (21.02.0515.03.05) by J. Trnovsky (Czech Republic), "A minute of absolute happiness" (03.03.06-14.03.06) with the participation of the Consulate General of the Czech Republic and others that help students get a deeper cultural insight into other countries. The SUSU's Hall of Arts also displayed amateur works by university teachers, employees and students.

A unique chance to meet authors of works and establish two-way communication between exhibition visitors and organizers fosters students' artistic education, develops selfawareness and promotes creativity. Introduction of authentic samples of fine arts, including global-level masterpieces, to students promotes involvement in great artistic values. The fact that these priceless collections have been gathered by Ural manufacturers, representatives of clerisy and ordinary residents of the South Urals and Chelyabinsk, offers a brand-new insight into the world of regional culture. Perception of art by students does not only raise their cultural level, but also moulds their self-awareness.

With a very high level of the pieces of art by renowned painters, diversity of topics, styles, genres, depth of the message and artistic content, exhibitions at the SUSU's Art Museum have become a visible phenomenon in the university's cultural life, its pride and competitive advantage. There is a constant search for new operating procedures of the "live museum" expressed in the creative support of exhibitions on the part of art students, lectures, concerts, meetings with artists, poets, composers. Publication activities are of great importance for publication of the exhibition materials, generation and accumulation of electronic media resources and their further use in the operation of the Virtual Museum. All this contributes to the development of students' cultural identity. One's self-identification with a community's cultural layer requires emotional and sensuous attitude to it. Initially, ideas of one's own culture are built, knowledge is accumulated and an individual becomes aware of his/her affiliation with the community: the cognitive component of identity is shaped. This level implies accumulation of information database (history of the country and 
region, nature of political, social and economic relations, layer of literary, mythopoietic and folk heritage). However, individual's attitude to this knowledge is indifferent and lacks emotional and sensuous overtone. The next stage occurs after a stable emotional attitude to the group has been established and the individual has recognized his/ her inextricable connection with his/her culture mediated by the attitude to it and assessment of its achievements. A body of knowledge of the cultural heritage of one's community and emotional attitude to it regulate the individual's behaviour, and thus construct the identity system (Smirnova, 2004). The exhibition activity of the SUSU's Art Museum helps promote all these drivers.

\section{References}

Ericsson, E. (1996). Identity: Youth and crisis. Moscow, 342 p.

Khamnaeva, A.Iu. (2007). Identichnost' kak sotsial'no-filosofskaia problema: dissertatsiia [Identity as a social and philosophical problem: thesis], Ulan-Ude, $208 \mathrm{p}$.

Kolesnik, M.A. (2014). Spetsifika obshcherossiyskoy i regional'noy kul'turnoy identichnosti studentov Sibirskogo federal'nogo universiteta na osnove rezul'tatov assotsiativnogo eksperimenta so slovom Rodina [Specificity of all-national and regional cultural identity of the Siberian federal university students on the basis of the associative experiment with the word "Motherland"], In Sovremennye problemy nauki i obrazovaniya [Modern problems of science and education], 4.

Koptseva, N.P. (2012). Kul'turologicheskaia baza formirovaniia obshchenatsional'noy rossiyskoy identichnosti v sibirskikh regionakh Rossiyskoy Federatsii [Cultorological base of the national Russian identity formation in Siberian regions of the Russian Federation], In Vestnik Volgogradskogo gosudarstvennogo universiteta [Bulletin of Volgograd State University], 3(18), 11-15.

Koptseva, N.P. (2013). Formirovanie rossiyskoy natsional'noy identichnosti i vozmozhnosti filosofii N.O. Losskogo dlia ratsional'nogo konstruirovaniia kontsepta "Natsiia" [Russian national identity development and possibilities philosophy by N.O. Losskiy for rational development of the "Nation" concept], In Sovremennye problemy nauki i obrazovaniia [Modern Problems of Science and Education], 6.

Koptseva, N.P., Kistova, A.V. (2015). Konstruirovanie etnokul'turnoy i obshchenatsional'noy identichnosti kak filosofskaia problema [Construction of ethnocultural and national identity as a philosophical problem], In Filosofiia i kul'tura [Philosophy and Culture], 1, 12-19.

Nazukina, M.V. (2009). Regional'naia identichnost'v sovremennoy Rossii: tipologicheskiy analiz [Regional identity in the present-day Russia: Typological analysis], Permian, $200 \mathrm{p}$.

Ozerina, A.A. (2012). Professional'naia identichnost' studentov bakalavriata [Professional identity of Bachelor students], Volgograd, 215 p.

Parfent'ev, N.P. (2010a). Kontseptsiia muzeia nauki i iskusstva Yuzhno-Ural'skogo gosudarstvennogo universiteta [Concept of the Science and Art Museum of the South Ural State University], In Nauchnometodicheskoe obespechenie deiatel'nosti universitetskogo muzeya iskusstv v sfere khudozhestvennoesteticheskogo obrazovaniia i vospitaniia studenchestva: materialy regional. nauch.-prakt. konf. [Scientific and methodological support of operations of the University Art Museum in art and aesthetic education and training of students: proceedings of the regional research and practical conference], 12-19.

Parfent'ev, N.P. (2010b). Sotrudnichestvo Yuzhno-Ural'skogo gosudarstvennogo universiteta i vedushchikh uchrezhdeniy iskusstv i kul'tury v sfere esteticheskogo vospitaniya studenchestva [Cooperation between the South Ural State University and leading art and cultural institutions in aesthetic 
education of students], In Nauchno-metodicheskoe obespechenie deyatel'nosti universitetskogo muzeia iskusstv v sfere khudozhestvenno-esteticheskogo obrazovaniia $i$ vospitaniia studenchestva: materialy regional. nauch.-prakt. konf [Scientific and methodological support of operations of the University Art Museum in art and aesthetic education and training of students: proceedings of the regional research and practical conference], 86-92.

Parfent'eva, N.V. (2009a). K razrabotke kontseptsii vystavochnoy i obrazovatel'noy deiatel'nosti universitetskogo zala iskusstv [On the elaboration of a concept for exhibition and education activities of the University Hall of Arts], In Vestnik Yuzhno-Ural'skogo gosudarstvennogo universiteta. Ser.: Sotsial'no-gumanitarnyye nauki [Bulletin of the South Ural State University: Social and humanitarian sciences], 12, 57-63.

Parfent'eva, N.V. (2009b). Osnovnyye napravleniia deiatel'nosti universitetskogo muzeia iskusstv i ikh nauchno-metodicheskoe obespechenie [Basic trends of activity of the University Art Museum and their scientific and methodological support], In Vestnik Yuzhno-Ural'skogo gosudarstvennogo universiteta. Ser.: Sotsial'no-gumanitarnyye nauki [Bulletin of the South Ural State University: Social and humanitarian sciences], 13, 48-51.

Parfent'eva, N.V. (2010a). Itogi proekta “Virtual'nyy filial Gosudarstvennogo Russkogo muzeya v YUUrGU”. Mezhdunarodnaia telekonferentsiia s uchastiem GRM i ego virtual'nykh filialov [Results of the "Virtual branch of the State Russian Museum in SUSU" Project. International teleconference with the participation of SRM and its virtual branches], In Nauchno-metodicheskoe obespechenie deyatel'nosti universitetskogo muzeia iskusstv $v$ sfere khudozhestvenno-esteticheskogo obrazovaniia $i$ vospitaniia studenchestva: materialy regional. nauch.-prakt. konf [Scientific and methodological support of operations of the University Art Museum in art and aesthetic education and training of students: proceedings of the regional research and practical conference], 92-97.

Parfent'eva, N.V. (2010b). Rol' iskusstva v kontseptsii razvitiia Yuzhno-Ural'skogo gosudarstvennogo universiteta [Role of arts in the development concept of the South Ural State University], In Nauchno-metodicheskoe obespechenie deyatel'nosti universitetskogo muzeia iskusstv $v$ sfere khudozhestvenno-esteticheskogo obrazovaniia i vospitaniia studenchestva: materialy regional. nauch.-prakt. konf [Scientific and methodological support of operations of the University Art Museum in art and aesthetic education and training of students: proceedings of the regional research and practical conference],6-11.

Parfent'eva, N.V. (2010c). Istoricheskiy rakurs formirovaniia universitetskikh muzeynykh kollektsiy [Historical aspect of the gathering of University Museum collections], In Nauchno-metodicheskoe obespechenie deyatel'nosti universitetskogo muzeia iskusstv v sfere khudozhestvenno-esteticheskogo obrazovaniia $i$ vospitaniia studenchestva: materialy regional. nauch.-prakt. konf [Scientific and methodological support of operations of the University Art Museum in art and aesthetic education and training of students: proceedings of the regional research and practical conference], 40-55.

Parfent'eva, N.V. (2010d). O printsipakh formirovaniia resursnoy bazy khudozhestvennoesteticheskogo obrazovaniia studenchestva na primere sozdaniia khudozhestvennoy kollektsii universitetskogo Muzeia iskusstv [On the principles of creating the resource base for art and aesthetic education and breeding of students based on art collection of the Art Museum], In: Vestnik YuzhnoUral'skogo gosudarstvennogo universiteta. Ser.: Sotsial'no-gumanitarnyye nauki [Bulletin of the South Ural State University: Social and humanitarian sciences], 14, 55-62. 
Parfent'eva, N.V. (2013). Rol' muzeia iskusstv Yuzhno-Ural'skogo gosudarstvennogo universiteta v khudozhestvenno-esteticheskom obrazovanii i vospitanii studenchestva [Role of the Art Museum of the South Ural State University in artistic and aesthetic education and breeding of students], In Nauka. Yuzhno-Ural'skiy gosudarstvennyy universitet: materialy 65-y nauchnoy konferentsii [Science. South Ural State University: proceedings of the 65th scientific conference], 191-194.

Parfent'eva, N.V., Parfent'ev, N.P. (2010). University art museum: the basic directions of activity and their scientific and teaching aids, In Journal of Siberian Federal University. Humanities \& Social Sciences, 3, (3), 412-420.

Pronina, T.S. (2016). Tipologiia religioznoy identichnosti: analitika religioznosti sovremennogo rossiyskogo obshchestva [Religious identity typology: Analysis of religiosity of the modern Russian society], St. Petersburg, 384 p.

Rozhkova, L.V. (2010). Identichnost' sovremennoy studencheskoy molodiozhi [Identity of modern students], In Izvestiya vysshikh uchebnykh zavedeniy. Povolzhskiy region. Obshchestvennyye nauki [News of higher educational institutions. Volga region. Social sciences], 2, 55-62.

Rusanov, Ia.A. (2010). Kontseptsiia sozdaniia mul'timedia programm po materialam ekspozitsionnoy deiatel'nosti Zala iskusstv [Concept of creating multimedia programs based on the materials of exhibition activities of the Hall of Arts], In Nauchno-metodicheskoe obespechenie deyatel'nosti universitetskogo muzeia iskusstv v sfere khudozhestvenno-esteticheskogo obrazovaniia $i$ vospitaniia studenchestva: materialy regional. nauch.-prakt. konf [Scientific and methodological support of operations of the University Art Museum in art and aesthetic education and training of students: proceedings of the regional research and practical conference], 31-40.

Schennikova, N.V. (2004). Traditsii drevnerusskogo iskusstva v kul'ture Urala: katalog ikon iz fondov Cheliabinskoy kartinnoy galerei [Traditions of the old Russian art in the culture of the Urals: catalogue of icons from Chelyabinsk Art Gallery], 16 p.

Shuklinova, M.V. (2005). Natsional'no-kul'turnaia identichnost' studentov provintsial'nykh vuzov [National and cultural identity of provincial university students], Moscow, $161 \mathrm{p}$.

Shul'gina, D.N. (2010). Globalizatsiia i kul'turnaia identichnost' [Globalization and cultural identity], Voronezh, $163 \mathrm{p}$.

Smakotina, N.L. (2010). Natsional'no-kul'turnaia identichnost' molodiozhi: sotsiologicheskiy metod otsenki [Youth's national and cultural identity: Sociologic method of assessment], In Vestnik moskovskogo universiteta. Ser. 18. Sotsiologiya i politologiya [Bulletin of the Moscow University. Ser. 18. Social and political science], 2, 59-79.

Smirnova, N.A. (2004). Regional'naia identichnost'v usloviiakh sovremennogo rossiyskogo obshchestva [Regional identity in the context of the modern Russian society], Volgograd, $188 \mathrm{p}$.

Trifonova, G.S. (2006). Kartina Apollinariia Vasnetsova «Gornoe ozero na Urale»: katalog vystavki zhivopisi A.Vasnetsova [Painting "Mountain Lake in the Urals" by Apollinariy Vasnetsov: catalogue of A. Vasnetsov painting exhibition], $16 \mathrm{p}$.

Trifonova, G.S. (2009a). Nauchno-metodicheskie podkhody i printsipy v uchebno-obrazovatel'noy deiatel'nosti khudozhestvennogo muzeya YUUrGU. Na primere raboty nad vystavkoy "Vasiliy Andreevich Neiasov (1926-1984). Vossoedinenie volzhskikh narodov s Rossiey, 1948-183: istoriia nenapisannoy kartiny" [Scientific and methodological approaches in training and education activities of the SUSU's Art Museum. Based on the exhibition "Vasily Andreevich Neyasov (1926-1984). 
Reunion of Volga Peoples with Russia, 1948-183: A story of a painting that has never been drawn], In Vestnik Yuzhno-Ural'skogo gosudarstvennogo universiteta. Ser.: Sotsial'no-gumanitarnyye nauki [Bulletin of the South Ural State University: Social and humanitarian sciences], 32, 69-82.

Trifonova, G.S. (2009b). Podlinnoe iskusstvo v prostranstve vuza: k formirovaniiu kontseptsii sotrudnichestva universitetskogo i gosudarstvennykh khudozhestvennykh muzeev [True art on the university premises: on the establishment of a concept for co-operation between university and state fine arts museums], In Vestnik Yuzhno-Ural'skogo gosudarstvennogo universiteta. Ser.: Sotsial'nogumanitarnyye nauki [Bulletin of the South Ural State University: Social and Humanitarian Sciences], 12, 78-82.

Trifonova, G.S. (2011). Russkiy kosmizm kak mirovozzrenie khudozhnikov “Amaravelly” [Russian Cosmism as the ideology of Amaravella artists], In Vestnik Yuzhno-Ural'skogo gosudarstvennogo universiteta. Ser.: Sotsial'no-gumanitarnyye nauki [Bulletin of the South Ural State University: Social and humanitarian sciences], 30, 85-90.

Voroshin, S.D. (2017a). Rol' universitetskogo muzeia v formirovanii kul'turnoy identichnosti studenchestva [Role of the university museum in the students' cultural identity development], In Vestnik Yuzhno-Ural'skogo gosudarstvennogo universiteta. Ser.: Sotsial'no-gumanitarnyye nauki [Bulletin of the South Ural State University: Social and humanitarian sciences], 1, 89-103.

Voroshin, S.D. (2017b). Vuzovskie muzei i izuchenie protsessov formirovaniia kul'turnoy identichnosti studenchestva [University museums and study of the processes of the students' cultural identity development], In Materialy nauchno-prakticheskoy konferentsii "Smysly, tsennosti, normy $v$ bytii cheloveka, obshchestva, gosudarstva" [Proceedings of the research and practice conference "Implications, values, norms in the existence of man, society, state"], 56-65.

\section{К проблеме формирования культурной идентичности студенчества}

\section{С.Д. Ворошин}

Южно-Уральский государственныий университет (Национальный исследовательский университет) Россия, 454080, Челябинск, пр. Ленина, 76

Статья посвящена изучению проблемы участия университетского музея в формировании культурной идентичности студенчества. Автором рассмотрена деятельность Зала искусств Художественного музея Южно-Уральского государственного университета (ЮУрГУ). Показано влияние художественного выставочного прочесса на конструирование различных уровней культурной идентичности студентов. Проведён анализ академических выставок Зала искусств различной направленности. Изучено влияние экспозиций художников Южного Урала на конструирование культурной идентичности студенчества. Продемонстрирована роль экспозищий мирового, общенационального и регионального значения в культурной жизни вуза.

Ключевые слова: университетские музеи, музейная деятельность вуза, культурная идентичность студенчества, Зал искусств Южно-Уральского государственного университета.

Научная специальность: 24.00.00 - культурология. 